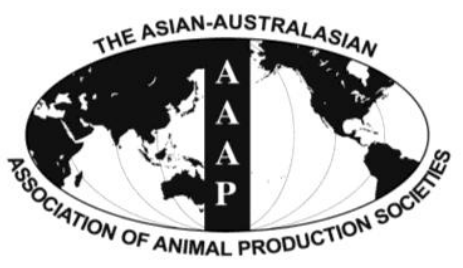

Open Access

Asian Australas. J. Anim. Sci.

Vol. 27, No. 9 : 1276-1284 September 2014

http://dx.doi.org/10.5713/ajas.2013.13814

www.ajas.info

pISSN 1011-2367 elSSN 1976-5517

\title{
Bale Location Effects on Nutritive Value and Fermentation Characteristics of Annual Ryegrass Bale Stored in In-line Wrapping Silage
}

\author{
K. J. Han*, M. E. McCormick ${ }^{1}$, S. M. Derouen ${ }^{2}$, and D. C. Blouin ${ }^{3}$ \\ School of Plant, Environmental, and Soil Sciences, Louisiana State University Agricultural Center, \\ Baton Rouge, LA 70803, USA
}

\begin{abstract}
In southeastern regions of the US, herbage systems are primarily based on grazing or hay feeding with low nutritive value warm-season perennial grasses. Nutritious herbage such as annual ryegrass (Lolium multiflorum Lam.) may be more suitable for preserving as baleage for winter feeding even with more intensive production inputs. Emerging in-line wrapped baleage storage systems featuring rapid wrapping and low polyethylene film requirements need to be tested for consistency of storing nutritive value of a range of annual ryegrass herbage. A ryegrass storage trial was conducted with 24-h wilted 'Marshall' annual ryegrass harvested at booting, heading and anthesis stages using three replicated in-line wrapped tubes containing ten round bales per tube. After a six-month storage period, nutritive value changes and fermentation end products differed significantly by harvest stage but not by bale location. Although wilted annual ryegrass exhibited a restricted fermentation across harvest stages characterized by high $\mathrm{pH}$ and low fermentation end product concentrations, butyric acid concentrations were less than $1 \mathrm{~g} / \mathrm{kg}$ dry matter, and lactic acid was the major organic acid in the bales. Mold coverage and bale aroma did not differ substantially with harvest stage or bale location. Booting and heading stageharvested ryegrass baleage were superior in nutritive value to anthesis stage-harvested herbage. Based on the investigated nutritive value and fermentation characteristics, individual bale location within in-line tubes did not significantly affect preservation quality of ryegrass round bale silages. (Key Words: Round Bale Silage, Baleage, Annual Ryegrass, Lolium multiflorum, Harvest Maturity, In-line Wrap, Dry Matter Concentration)
\end{abstract}

\section{INTRODUCTION}

Dairy operations depend heavily on annual ryegrass for high quality winter herbage in the deep south of the USA. In a study conducted in Georgia, USA, 50\% heading stage ryegrass could produce herbage of sufficient net energy and protein to produce $0.7 \mathrm{~kg} / \mathrm{d}$ gains in beef calves

\footnotetext{
* Corresponding Author: K. J. Han. Tel: +1-225-578-1305, Fax: +1-225-578-1403, E-mail: Khan@agcenter.lsu.edu

1 Southeast Region Office, Louisiana State University Agricultural Center, Hammond, LA 70403 USA.

2 Dean Lee Research Station, Louisiana State University Agricultural Center, Alexandria, LA 71302 USA.

3 Department of Experimental Statistics, Louisiana State University Agricultural Center, Baton Rouge LA 70803 USA. Submitted Dec. 12, 2013; Revised Feb. 26, 2014; Accepted Mar. 8, 2014
}

(McCormick and Fales, 1985). Another study demonstrated that substituting ryegrass silage for corn silage in a milking cow diet elicited improved fiber digestibility and milk production without body weight loss (Bernard et al., 2002).

A long term assessment of annual ryegrass produced in commercial farms indicated that crude protein $(\mathrm{CP})$ and total digestible nutrients (TDN) of silages were superior to those of hay by 30 and $48 \mathrm{~g} / \mathrm{kg}$ dry matter (DM), respectively (Han et al., 2008), resulting in the greater value of harvesting ryegrass for silage than possible for ryegrass harvested as hay. Approximately $70 \%$ of annual ryegrass biomass is harvested between March and early May when field curing can be erratic due to alternating weather of heavy rain and drought. Round bale silage was recognized as one of the most effective herbage storage options in the areas of frequent rain due to its great flexibility with 
weather changes (Haigh, 1990). Individually wrapped bale silage is easily transported and saves the capital investment needed for hay barns.

Although round bale silage has been proposed as an alternative herbage storage practice where hay making is challenging, storing wilted herbage in individually wrapped bales is occasionally vulnerable to spoilage due to poor fermentation or broken plastic wrap. Weak fermentation or restricted fermentation of round bale silage results from a large surface area to volume ratio, variable moisture concentration in herbage, and low packing density compared with precision chopped grass silage (McEniry et al., 2008). These conditions may create more opportunities for spoilage from aerobic deterioration by mold and listeria (Muck and Shinners, 2001; McEniry et al., 2008). Low lactic acid content in silage and wide spread fungal contamination on bale surfaces was commonly found in producers' round bale silage having damaged polyethylene film wrap (O'Brien et al., 2007a). Another survey on round bale silage also indicated that fermentation of round bale silage was generally weak and the $\mathrm{pH}$ of $17.9 \%$ of round bale silage samples was above 6.5 (Huhnke et al., 1997). Management of air-tight sealing was the key factor in prevention of mold and other aerobic pathogen growth in round bale silage. Generally, silage bales wrapped with six layers of stretch film were more secure against physical damage during bale handling than bales with fewer layers (O'Brien et al., 2007b).

Wrapping individual bales packed tightly each other in a continuous bale tube requires plastic for the sides only thereby providing considerable savings in plastic film compared to individually wrapped bales that must be completely wrapped on sides and ends (Hersom and Kunkle, 2003). It is also anticipated that reduced surface area achieved by using an in-line wrapper may reduce heat dissipation and vulnerability of film to tearing. Since bales are ensiled in one continuous airtight film wrap, there may be substantial opportunities for aerobic spoilage due to air pockets made by uneven bale junctions, uneven floor, bale locations within an in-line wrapped tube, or by wrap punctures. Yet, little information exists documenting nutritional consistency of baleage from in-line stretchwrapped tubes. This study was conducted to investigate changing nutritive value patterns and differences in fermentation aspects of annual ryegrass baleage stored at three advancing harvest stages using an in-line wrapper. A second objective was to evaluate fermentation patterns and nutritional value of ryegrass bales stored in different locations within in-line wrapped tubes.

\section{MATERIAL AND METHODS}

\section{Annual ryegrass cultivation and harvest}

Field studies were conducted at the Louisiana State
University Agricultural Center Rosepine Research Station in Rosepine, Louisiana $\left(30^{\circ} 95^{\prime} \mathrm{N}, 93^{\circ} 28^{\prime} \mathrm{W}\right)$ to investigate the effects of maturity and bale location in in-line wrapped tubes of annual ryegrass round bale silage. Soils were a Bowie fine sandy loam (loamy, siliceous, thermic Plinthic Paleudult). Cultivar 'Marshall' annual ryegrass was planted in early October, 2009 at a seeding rate of $28 \mathrm{~kg} / \mathrm{ha}$ pure live seed using a no-till drill planter. The ryegrass pastures were divided into three paddocks containing 4.1, 4.1, and 2.0 ha and grazed through the winter. In early spring, 103 $\mathrm{kg} / \mathrm{ha}$ of $\mathrm{N}$ was applied as urea after pastures were uniformly mob grazed to 4 to $8 \mathrm{~cm}$ stubble height. Beginning from April 5, 2010, pastures were harvested using a flail-type mower at booting stage and wilted for approximately $24 \mathrm{hrs}$ in windrows. As ryegrass pastures reached heading (April 20) or anthesis stages (April 30), similar harvest management was applied.

\section{Bale preparation using in-line wrapper}

At each harvest stage, a total of thirty $1.5 \mathrm{~m}$ (length) by $1.8 \mathrm{~m}$ (diameter) round bales were made using a John Deere 566 model baler (John Deere, Moline IL, USA). Each bale was weighed using a digital platform scale and three core samples from each side of a bale were collected in an airtight plastic sample bag and temporarily stored in an icefilled cooler. The samples were moved into a freezer on the same day and stored until laboratory analyses were available. After weighing individual bales and collecting core samples, each bale was labeled using a plastic tag to track bale location within in-line wrap.

In-line bale wrapping began with placing a labeled bale next to a round bale hay capped with plastic bag, which served as a terminal bale. The plunger of the in-line bale wrapper (TRL 5000, TubeLine Manufacturing Inc., Elmira, Ontario, Canada) packed bales each other on platform and wrapped with six layers of polyethylene film (Sunfilm Silage Wrap, AEP Industries Inc., Waxahachie, TX, USA). Another hay bale capped with a plastic bag was loaded after the 10th bale and wrapped with six layers of plastic films. Each harvest maturity was replicated with three in-line wrapped tubes containing a total of ten bales and two terminal hay bales.

\section{Round bale silage evaluation and sample analysis}

After a six month storage period, bales were opened and immediately evaluated for exterior mold coverage $(1=$ clean of mold, $5=100 \%$ coverage), color, and aroma ( $1=$ heat damaged, $3=$ optimum, $5=$ moldy). There was no obvious damage to the integrity of the outer wrapping upon opening.

Post-storage core samples were taken from each side in exactly the same manner as the pre-storage bales. Wet silage samples were sub-sampled for determination of $\mathrm{pH}$, 
lactic acid, ammonia, and volatile fatty acid (VFA) concentrations. Wet silage samples were homogenized for $30 \mathrm{~s}$ in distilled water $(10: 1 \mathrm{w} / \mathrm{w})$. Silage $\mathrm{pH}$ was measured on the homogenate after filtering through four layers of cheesecloth. Water soluble carbohydrate (WSC) was analyzed according to Johnson et al. (1966) which is a modification of Dubois et al. (1956). Aliquots of $1-\mathrm{mL}$ filtrate were mixed with $0.2 \mathrm{~mL}$ of $25 \% \quad(\mathrm{v} / \mathrm{v})$ metaphosphoric acid and centrifuged at $5^{\circ} \mathrm{C}$ at $21,600 \mathrm{~g}$ for 20 min. Volatile fatty acids in the supernatant were determined according to Sukhija and Palmquist (1988) and lactic acid concentration was determined according to Adams et al. (1984) using HPLC (PerkinElmer Inc., Foster City, CA, USA).

Another subsample was dried at $55^{\circ} \mathrm{C}$ for $72 \mathrm{~h}$ to determine DM concentration and saved for nutritive value analyses. Dried forage samples were ground to pass a 1-mm screen using a Wiley mill (Arthur H. Thomas Company, Philadelphia, PA, USA). Total $\mathrm{N}$ concentration and acid detergent insoluble nitrogen (ADIN) were determined by rapid combustion using a LECO FP-528 Protein Analyzer (LECO Corp. St. Joseph, MI, USA), and CP was calculated as $\mathrm{N} \times 6.25$. Duplicate $0.50 \mathrm{-g}$ samples were used to determine in vitro true digestibility (IVTD) by the methods of Goering and Van Soest (1970). Neutral detergent fiber (NDF) and acid detergent fiber (ADF) concentrations were determined with an Ankom Model 200 fiber analyzer (Ankom Technology, Macedon, NY, USA) using a sodium sulphite procedure (Robertson and Van Soest, 1981). Weather data were collected from Louisiana State University Agricultural Center weather stations near the experimental field.

\section{Data analysis}

A completely randomized design with repeated measures in space was used to analyze pre- and post-storage nutritive value, fermentation end products, and bale characteristics. There were three in-line tubes for each harvest stage. Each tube had 10 bales. Within each tube, the relative locations of the bales were numbered from 1 to 5 , starting from each end and ending in the middle of a wrapped tube, that is, there were two bales at each relative location. Bale storage (pre-preserved wilted forage vs post- preserved silage), and relative bale location effects were fixed. Tube, relative location by tube, and bale effects were random. The GLIMMIX procedure of SAS 9.2 (SAS Institute, 2009) was used to detect treatment differences for the response variables.

\section{RESULTS}

Harvest stage effect was significant for all round bale silage characteristics measured, but no within tube bale location effects were detected (Table 1). Storage affected most of bale silage aspects except for DM after six month storage $(p=0.51)$. Also, interactions of bale location with harvest stage or storage were not significant for most bale characteristics investigated in this study. The interactions that occurred between harvest stage and pre and postharvest characteristics (storage) were significant for bale weight, WSC, ADIN, ADF, and NDF, indicating that differences in nutritive value and fermentation of annual ryegrass baleage was mostly determined by forage condition at harvest. Three way interactions were only significant for WSC and ADIN to total $\mathrm{N}$ ratio. Therefore, data are presented as harvest stage means by pre- and poststorage in Table 2 or by harvest stage only in Table 3.

\section{Bale characteristics and chemical composition}

Pre-ensiled bale weight at booting stage was greater than that of bales at heading or anthesis stage by 27 and 78 $\mathrm{kg}$, respectively (Table 2). After six months of storage, the weights of booting-stage bales decreased by $8 \%$ from the pre-storage weight while those of heading and anthesis stage bales changed by $4 \%$ or a non-detectable amount, respectively. As presented in Table 1 and 2, WSC concentrations in baleages was affected by the interactions between harvest stage, bale location in the tube, and storage, which resulted in complex of three way harvest management factors. There was a tendency that greater concentration of WSC in forage at less mature stage. Pairwise comparisons of nutritive value between pre and post-ensiled ryegrass silage appeared to vary considerably across harvest stages. All chemical analyses of post storage annual ryegrass demonstrated declines in baleage nutritive value regardless of harvest stage $(\mathrm{p}<0.05)$ (Table 2$)$. The

Table 1. Summary of effects from analysis of variance for bale characteristics and nutritive value of annual ryegrass (Lolium multiflorum Lam.) harvested at booting, heading, and anthesis stages

\begin{tabular}{lccccccccc}
\hline & $\begin{array}{c}\text { Bale } \\
\text { weight }\end{array}$ & $\begin{array}{c}\text { Bale } \\
\text { density }\end{array}$ & DM & WSC & CP & $\begin{array}{c}\text { ADIN to } \\
\text { total N }\end{array}$ & ADF & NDF & IVTD \\
\hline Bale location (BL) & $\mathrm{ns}$ & $\mathrm{ns}$ & $\mathrm{ns}$ & $\mathrm{ns}$ & $\mathrm{ns}$ & $\mathrm{ns}$ & $\mathrm{ns}$ & $\mathrm{ns}$ & $\mathrm{ns}$ \\
Storage (ST) & $<0.01$ & $<0.01$ & $\mathrm{~ns}$ & $<0.001$ & $<0.001$ & $<0.05$ & $<0.001$ & $<0.001$ & $<0.001$ \\
BL $\times$ ST & $<0.05$ & $<0.05$ & $\mathrm{~ns}$ & $<0.001$ & $\mathrm{~ns}$ & $\mathrm{~ns}$ & $\mathrm{~ns}$ & $\mathrm{~ns}$ & $\mathrm{~ns}$ \\
\hline
\end{tabular}

DM, dry matter; WSC, water soluble carbohydrate; CP, crude protein; ADIN, acid detergent insoluble nitrogen; ADF, acid detergent fiber; NDF, neutral detergent fiber; IVTD, in vitro true digestibility; ns, not significant.

${ }^{1}$ Bale order within in-line wrapper tubes. 
Table 2. Pre- and post-storage characteristics of annual ryegrass (Lolium multiflorum Lam.) round bale silages harvested at booting, heading, and anthesis harvest stages

\begin{tabular}{|c|c|c|c|c|c|c|}
\hline & \multicolumn{6}{|c|}{ Harvest stage } \\
\hline & \multicolumn{2}{|c|}{ Booting } & \multicolumn{2}{|c|}{ Heading } & \multicolumn{2}{|c|}{ Anthesis } \\
\hline & Pre-storage & Post-storage & Pre-storage & Post-storage & Pre-storage & Post-storage \\
\hline Dry bale weight (kg) & $383^{\mathrm{a}}$ & $354^{\mathrm{b}}$ & $356^{\mathrm{a}}$ & $341^{\mathrm{b}}$ & $305^{\mathrm{a}}$ & $309^{\mathrm{a}}$ \\
\hline Bale density $\left(\mathrm{kg} / \mathrm{m}^{3}\right)$ & $100^{\mathrm{a}}$ & $93^{\mathrm{b}}$ & $93^{\mathrm{a}}$ & $89^{\mathrm{b}}$ & $80^{\mathrm{a}}$ & $81^{\mathrm{a}}$ \\
\hline DM concentration $(\mathrm{g} / \mathrm{kg})$ & $470^{\mathrm{a}}$ & $463^{\mathrm{a}}$ & $610^{\mathrm{a}}$ & $608^{\mathrm{a}}$ & $765^{\mathrm{a}}$ & $761^{\mathrm{a}}$ \\
\hline WSC (g/kg DM) & $41.2^{\mathrm{a}}$ & $30.7^{\mathrm{b}}$ & $44.9^{\mathrm{a}}$ & $29.7^{\mathrm{b}}$ & $37.0^{\mathrm{a}}$ & $15.4^{\mathrm{b}}$ \\
\hline $\mathrm{CP}(\mathrm{g} / \mathrm{kg} \mathrm{DM})$ & $164^{\mathrm{a}}$ & $142^{\mathrm{b}}$ & $133^{\mathrm{a}}$ & $119^{\mathrm{b}}$ & $132^{\mathrm{a}}$ & $109^{\mathrm{b}}$ \\
\hline ADIN (\% of total N) & $12.5^{\mathrm{b}}$ & $13.8^{\mathrm{a}}$ & $19.2^{\mathrm{a}}$ & $20.6^{\mathrm{a}}$ & $18.2^{\mathrm{b}}$ & $31.9^{\mathrm{a}}$ \\
\hline $\mathrm{ADF}(\mathrm{g} / \mathrm{kg} \mathrm{DM})$ & $302^{\mathrm{b}}$ & $398^{\mathrm{a}}$ & $326^{\mathrm{b}}$ & $391^{\mathrm{a}}$ & $327^{\mathrm{b}}$ & $424^{\mathrm{a}}$ \\
\hline NDF (g/kg DM) & $548^{\mathrm{b}}$ & $606^{\mathrm{a}}$ & $609^{\mathrm{b}}$ & $617^{\mathrm{a}}$ & $659^{\mathrm{b}}$ & $673^{\mathrm{a}}$ \\
\hline IVTD (g/kg DM) & $795^{\mathrm{a}}$ & $691^{\mathrm{b}}$ & $724^{\mathrm{a}}$ & $657^{\mathrm{b}}$ & $679^{\mathrm{a}}$ & $601^{\mathrm{b}}$ \\
\hline
\end{tabular}

DM, dry matter; WSC, water soluble carbohydrate; CP, crude protein; ADIN, acid detergent insoluble nitrogen; ADF, acid detergent fiber; NDF, neutral detergent fiber; IVTD, in vitro true digestibility.

${ }_{a, b}$ Within the same harvest stage, means followed by different letters are significantly different at $\mathrm{p}<0.05$.

Bale location within in-line tube was not significant for all the fermentation end-products.

differences in bale weight, $\mathrm{CP}, \mathrm{ADIN}, \mathrm{ADF}$, and NDF between post-storage and pre-storage annual ryegrass differed significantly by harvest stage. The CP concentration decreased up to $17 \%$ in anthesis ryegrass baleage compared to earlier harvests. However, compared to pre-storage of booting, heading and anthesis stages ryegrass, the ADIN concentrations in post-storage baleage increased by $10.4 \%, 7.3 \%$, and $75 \%$, respectively (Table 2 ). Greater IVTD was obtained in booting stage ryegrass than in the other two more advanced harvest stages in both preand post- storage samples $(\mathrm{p}<0.01)$. Decrease in IVTD after storage ranged from $9.2 \%$ to $13.0 \%$ and did not differ by bale location $(\mathrm{p}=0.98)$.

\section{Fermentation of annual ryegrass in in-line wrapped tubes}

In addition to differences in nutritive value,

Table 3. Fermentation characteristics of annual ryegrass (Lolium multiflorum Lam.) round bale silage and summary of effects from analysis of variance

\begin{tabular}{lccc}
\hline & \multicolumn{3}{c}{ Harvest stage } \\
\cline { 2 - 4 } & Booting & Heading & Anthesis \\
\hline $\mathrm{pH}$ & $5.28^{\mathrm{b}}$ & $5.43^{\mathrm{b}}$ & $6.59^{\mathrm{a}}$ \\
Titratable acidity (meq/g) & $1.25^{\mathrm{a}}$ & $1.01^{\mathrm{a}}$ & $0.10^{\mathrm{b}}$ \\
Ammonia $(\mathrm{g} / \mathrm{kg} \mathrm{TN})$ & $21.9^{\mathrm{a}}$ & $13.4^{\mathrm{b}}$ & $15.2^{\mathrm{b}}$ \\
Lactic acid $(\mathrm{g} / \mathrm{kg} \mathrm{DM})$ & $26.2^{\mathrm{a}}$ & $13.4^{\mathrm{b}}$ & $0.50^{\mathrm{c}}$ \\
Acetic acid (g/kg DM) & $10.3^{\mathrm{a}}$ & $4.3^{\mathrm{b}}$ & $1.1^{\mathrm{c}}$ \\
Propionic acid $(\mathrm{g} / \mathrm{kg} \mathrm{DM})$ & $0.40^{\mathrm{a}}$ & $<0.001^{\mathrm{c}}$ & $0.01^{\mathrm{b}}$ \\
Isobutyric acid (g/kg DM) & $1.40^{\mathrm{a}}$ & $0.01^{\mathrm{b}}$ & $0.01^{\mathrm{b}}$ \\
Butyric acid (g/kg DM) & $0.34^{\mathrm{a}}$ & $0.02^{\mathrm{b}}$ & $0.02^{\mathrm{b}}$ \\
Total VFA (g/kg DM) & $38.7^{\mathrm{a}}$ & $17.7^{\mathrm{b}}$ & $1.70^{\mathrm{c}}$ \\
Lactic to VFA ratio & $0.64^{\mathrm{a}}$ & $0.67^{\mathrm{a}}$ & $0.25^{\mathrm{b}}$ \\
\hline TN, total nitrogen; DM, dry matter; VFA, volatile fatty acid. \\
a,b,c Within the same row, means followed by different & letters are \\
significantly different at $\mathrm{p}<0.05$. & \multicolumn{4}{l}{}
\end{tabular}

fermentation characteristics were also found to vary substantially with maturity at ryegrass harvest. Round bales at heading and anthesis stages produced lower concentrations of fermentation end-product than at booting (Table 3). Lactic acid to total VFA ratio of booting, heading, and anthesis were $64 \%, 67 \%$, and $25 \%$, respectively $(\mathrm{p}<0.05)$. In the case of anthesis maturity, baleage contained less than $1.0 \mathrm{~g} / \mathrm{kg}$ DM lactic acid along with extremely low concentrations of propionic and butyric acids.

Visual evaluation of surface mold coverage differed slightly in individual bales within in-line wrapped tubes, but for the most part mold score distributions appeared to follow a random pattern (Figure 3a). However, anthesis stage bales exhibited more inconsistent surface mold scores within a tube. Across harvest stages, mean mold scores were 3.0 and 2.7 for the south end and north end, respectively while middle bales (the mean of bale number 5 and 6) averaged 2.5. These slight differences in mold scores indicate that bales located on the outer edge of a tube had similar air-tight conditions as inner bales.

\section{DISCUSSION}

\section{Impact of harvest maturity and within-tube bale location}

The different DM concentrations of the forage mass at each harvest stage generally affected mean bale weight change and drier bales shrunk less than wetter bales after storage. The DM concentrations in the forage in the current study were greater than the range of DM concentration for ordinary round bale silages, especially at heading and anthesis stages. Wilting annual ryegrass for round bale silage may require extra caution in the late spring because of the dry weather conditions prevalent during this time of a year. Cutting one morning and baling the next morning ( 24 
$\mathrm{h}$ wilt), under unusually dry conditions increased forage DM concentration to greater than $600 \mathrm{~g} / \mathrm{kg}$ for the two later harvests. In 2010, daily rainfall were at historical lows for April (Figure 1) and from February through May monthly temperatures were above normal (Figure 1). The wilted anthesis stage ryegrass contained only $234 \mathrm{~g} / \mathrm{kg}$ moisture, which was considered extremely low moisture forage to be preserved in round bale silage. This excessively dried forage mass did not make as high density round bale as the wetter annual ryegrass wilted at booting stage. The mean packing density of the fresh booting stage forage was greater than that of heading or of anthesis stage by up to $421 \mathrm{~kg} / \mathrm{m}^{3}$. However, on DM basis, bale density differences became less extreme compared with density expressed on a wet basis. As a result, it appears that harvest and wilting at the booting stage generated more favorable conditions for establishing an anaerobic condition in bales than the other two more advanced stages.

The WSC concentrations in forage may have been affected more sensitively than other nutrient components by harvesting and ensiling management techniques used in this study. Comparison of WSC in pre- and post-storage samples showed heading as a more desirable harvest stage for baleage than later stages as a consequence of more fermentable sugar potential (Table 2). Based on nutritive value and DM yield of annual ryegrass, McCormick (2006) suggested harvest stages between booting and early heading stages as most desirable for baleage production. The degree of WSC concentration difference in pre-storage bales by within-tube bale location and harvest stage was less evident in post-storage bales (Figure 2). Overall, forage WSC concentrations did not exhibit any conclusive pattern with

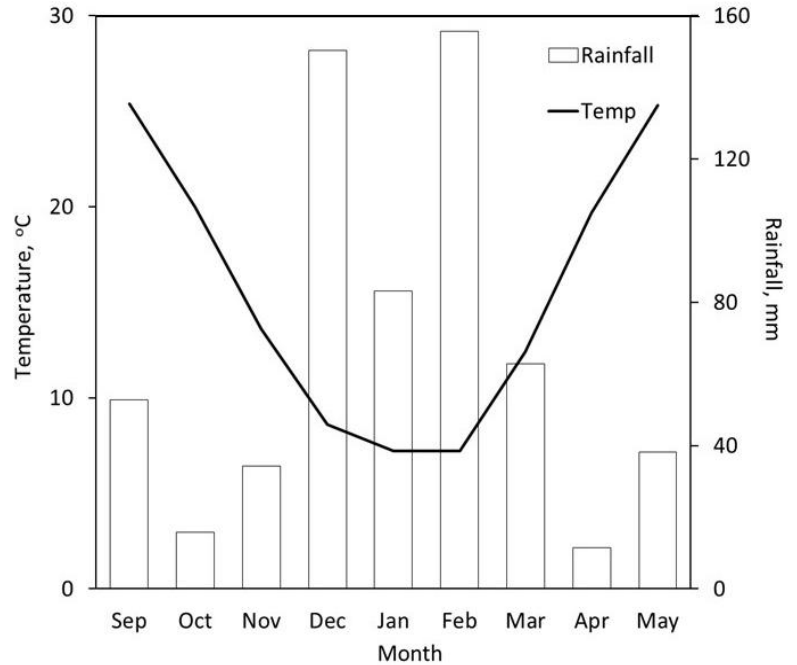

Figure 1. Mean monthly temperature and rainfall at the Rosepine Research Station, Louisiana, USA during the study.

bale location within tube.

Nutritive values of annual ryegrass harvested at booting, heading, and anthesis differed significantly after $24 \mathrm{~h}$ wilting (Table 2), indicating that maturity at harvest was the primary factor determining initial forage nutritive value. Nutritive value differences were maintained or slightly altered in the baleage. Most mean separations for CP, ADF, and digestibility in pre-storage bales occurred between booting stage and heading or booting and anthesis stages, indicating that the nutritive value decline of annual ryegrass became more substantial as advancing to heading stage. An investigation on nutritive value changes in annual ryegrass cultivars indicated a rapid decline in energy value from the beginning of seed-head emergence to the full-head stage

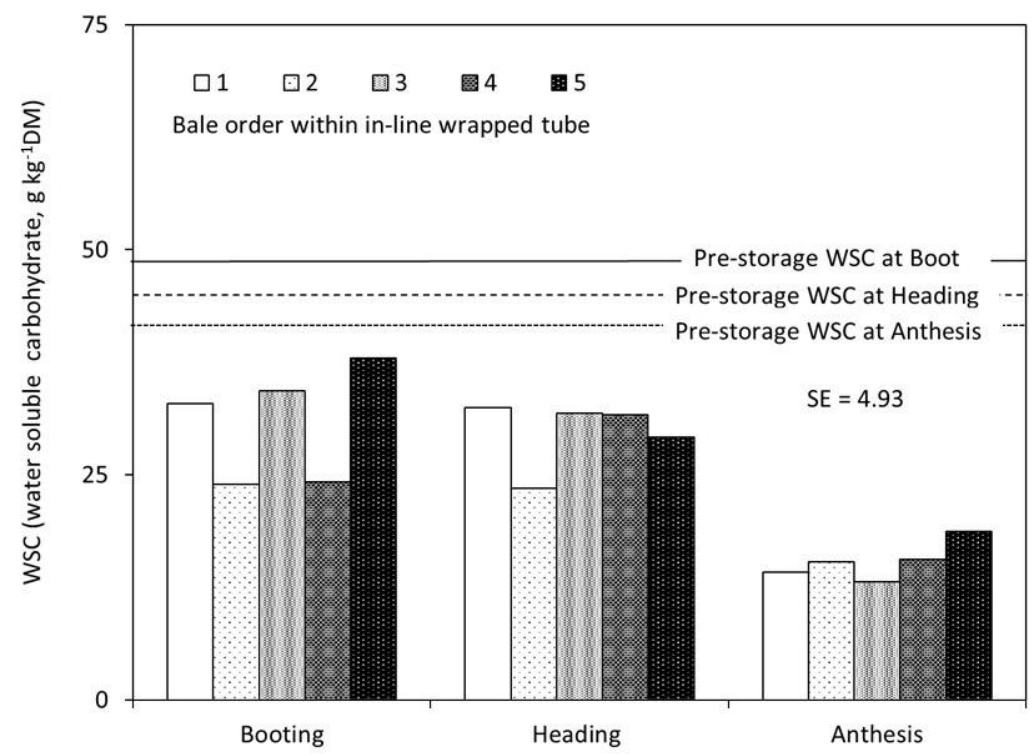

Figure 2. Water soluble carbohydrate concentration in pre- and post-storage annual ryegrass (Lolium multiflorum Lam.) round bale silage ensiled in in-line wrap tubes at booting, heading, and anthesis stages, showing bale location from 1 to $5(1=$ bales at the both ends and increasing number indicating close to the middle of the tube). 
(McCormick and Fales, 1985).

It is presumed that drier baleage, such as present in anthesis-stage bales, may have been conducive to more heating from aerobic respiration which leads to elevated ADIN concentrations. Han et al. (2006) observed, high bale core temperatures only during the first 14 days post-storage for alfalfa baleage containing $705 \mathrm{~g} / \mathrm{kg}$ DM. However in the present study, the respiration at early storage probably consumed significant amount of available sugars and generated more heat-bound protein by the Maillard reaction in anthesis stage ryegrass baleage. Initial bale density on a wet basis of anthesis-stage baleage was only $100 \mathrm{~kg} / \mathrm{m}^{3}$ while those of booting or heading stage bales were approximately $100 \%$ and $50 \%$ greater, respectively. This low bale density likely led to excess oxygen retention in the bale which was a major factor leading to bale heating and high forage ADIN concentrations.

Commonly, ADF and NDF concentrations in baleage increased after storage. In this study, the concentration increase in ADF ranged from $20 \%$ to $31 \%$ while those of NDF ranged from $10 \%$ to $17 \%$. This difference in concentration change may reflect relatively higher concentrations of ligno-cellulose or artifact fiber related to heating. Dewar et al. (1963) reported that a maximum of $22.8 \%$ of hemicellulose extracted from Lolium perenne was hydrolysable to xylose through hemicellulase reaction during ensiling and degradation of hemicellulose to sugar was maximized at near $\mathrm{pH}$ 6. The current study's high $\mathrm{pH}$
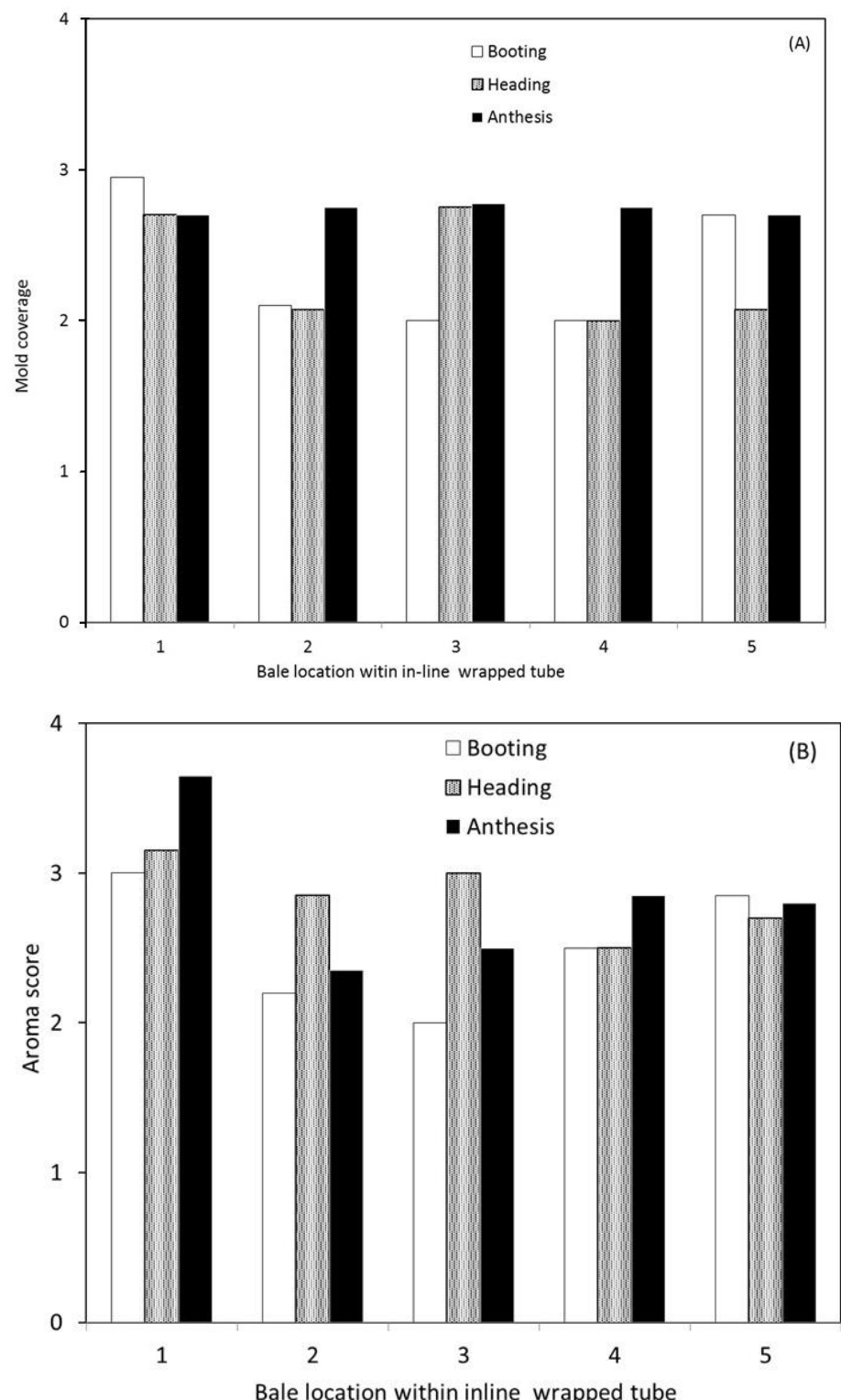

Figure 3. Visual baleage evaluation of post-storage annual ryegrass (Lolium multiflorum Lam.) round bale silage ensiled in in-line wrap tubes at booting, heading, and anthesis stages, showing bale location from 1 to $5(1=$ bales at the both ends and increasing number indicating close to the middle of the tube). The bale mold scores and bale aromatic scores were from $1=$ clean, $5=100 \%$ cover (a), and aroma $1=$ heat damaged, $3=$ optimum, $5=$ moldy (b), respectively. 
baleage may have incurred some portion of hemicellulose degradation through several interrelated mechanisms such as increased enzymatic reaction, bacterial function, or acid hydrolysis. Hemicellulose loss due to acid hydrolysis during the ensiling ranged $3.8 \%$ to $5.2 \%$ of grass forage DM (McEniry et al., 2008). It is also possible that restricted sugar availability from excess heating and Maillard reactions led to an increased use of hemicellulose during the restricted bale silage fermentation. Consequently, NDF changes during storage were minimal since increases in artifact lignocellulose balanced decreases in forage hemicellulose concentrations. These findings are similar to those of McCormick et al. (2002) where ryegrass bales stored in tubes contained $14.5 \%$ more ADF post-ensiling than pre-ensiling, but NDF increases were negligible.

It seems that degradation of nutrients occurred proportionally and did not result in digestibility differences among the treatments. Based on lack of bale location effects for most of nutritive values, the in-line wrapping system appeared capable of maintaining the necessary uniform ensiling conditions required for successful round bale silage storage, regardless of bale location with in tubes.

\section{Fermentation within in-line wrapped tubes}

Low fermentation end-product concentration and low acidity are consistent indicators of restricted fermentation in low moisture forage (Muck et al., 1990; Han et al., 2006; Borreani and Tabacco, 2006; Martinson et al., 2011).

Since WSC concentrations did not differ substantially by harvest stage, restricted fermentation particularly for the anthesis stage likely occurred due to inadequate moisture for lactic acid bacteria growth (Muck et al., 2006). Regardless, mean baleage $\mathrm{pH}$ was greater than 5.0 for all baleages. Total titratable acidity of annual ryegrass silage made with anthesis stage ryegrass was only one tenth of the acidity of booting or heading stage (Table 3). In earlier research, forage DM concentration was negatively correlated with silage acetic acid, butyric acid, and ammonia-N concentrations while damage on wrap more negatively affected lactic acid content (O'Brien et al., 2007a). Even with the high $\mathrm{pH}$ evident in the ryegrass baleages, low acidity did not necessarily indicated spoiled baleage since lactic acid was the major portion of the acid in the stored forage. Overall, the lactic acid concentration in the current study was less than half of lactic acid concentration in another ryegrass baleage study in which forage was ensiled at $335 \mathrm{~g} / \mathrm{kg}$ DM concentration (McCormick et al., 1998).

A secondary fermentation study with wheat (Triticum aestivum L.) and orchardgrass (Dactylis glomerata L.) round bales stored in in-line wrapped tubes demonstrated aerobic stability of exposed baleage for up to $32-\mathrm{d}$ at $0.6^{\circ} \mathrm{C}$ to $19.4^{\circ} \mathrm{C}$ ambient temperature (Rhein et al., 2005). As demonstrated in that study, high $\mathrm{pH}(>5.0)$ silages made from wheat and orchardgrass containing high DM (544 to $624 \mathrm{~g} / \mathrm{kg}$ ) were aerobically stable due to reduced lactic acid bioavailability and low bale moisture concentration (Rhein et al., 2005). The current study's weak fermentation but high DM concentration may be advantageous for winter feeding when cooler temperatures may limit aerobic deterioration.

As with perennial ryegrass (Lolium perenne L.), annual ryegrass contains a high concentration of fermentable carbohydrates in stems and approximately $50 \%$ of sugar is present as fructan (McGrath, 1988). Haigh (1990) reported $37 \mathrm{~g} / \mathrm{kg}$ as the minimum WSC concentration for ensiling ryegrass at $230 \mathrm{~g} / \mathrm{kg} \mathrm{DM}$ concentration. Although DM concentrations in the current study were not comparable to Haigh (1990)'s study, the WSC concentration at the three harvest stages would be sufficient for lactic acid fermentation. Nicholson et al. (1991) reported that DM concentrations from 350 to $400 \mathrm{~g} / \mathrm{kg}$ generated a stronger fermentation with a faster $\mathrm{pH}$ drop and more lactic acid production at the early storage stage than forage tested containing 450 to $500 \mathrm{~g} / \mathrm{kg}$ DM. These data are supported by McCormick et al. (1998) in which annual ryegrass baleage containing $335 \mathrm{~g} / \mathrm{kg}$ had a $\mathrm{pH}$ of 4.8 and lactic acid concentration $51.0 \mathrm{~g} / \mathrm{kg}$ DM. Ammonia concentration was greater in bales made with booting stage maturity forage than those in heading or anthesis stages (Table 3). As reported in Nicholson et al. (1991)'s round bale silage study, ammonia to total $\mathrm{N}$ ratio for high moisture baleage (booting stage) was higher than low moisture baleages (heading or anthesis) after six months of storage.

\section{Visual and sensory evaluation}

According to Martinson et al. (2011), wrapping high moisture hay was just as effective in limiting mold growth as was achieved with hay baled at $124 \mathrm{~g} / \mathrm{kg}$ moisture. The low moisture ryegrass in this study, which was not suitable for baleage and was still too wet for successful hay production, could be preserved as baleage using the in-line wrapper to eliminate oxygen penetration. A sensory test also indicated that bale aroma scores were distributed in a random pattern (Figure 3b). Several bales located on the tube interior possessed a favorable silage aroma and also several bales located at the end of tubes scored high for aroma indicating that bales were preserved without major deterioration. Bales stored at anthesis had a broader range of aroma evaluation scores than booting or heading stage, indicating somewhat variable storage conditions with drier biomass.

\section{IMPLICATIONS}

Since annual ryegrass yield and nutritive value are 
optimal in the southeast US when hay curing conditions are usually less than optimal, a more dependable storage strategy requiring shorter forage wilting times is required. Round bale silage is a flexible forage conservation system that minimizes wilting time thereby allowing earlier harvest of winter annual forages such as annual ryegrass. This study demonstrated that optimum stage of harvest for ryegrass baleage was at booting or heading and that low moisture baleage crops could be stored with an in-line wrapper without severe quality loss. Moreover, bales preserved in different locations within in-line wrapped tubes did not demonstrate any consistent nutritive value or fermentation pattern differences.

\section{ACKNOWLEDGMENTS}

Authors thank Louisiana Cattlemen's Association for partial funding required to conduct this study.

\section{REFERENCES}

Adams, R. F., R. L. Jones, and P. L. Conway. 1984. High performance liquid chromatography of microbial acid metabolites. J. Chromatogr. B. Biomed. Sci. Appl. 336:125137.

Bernard, J. K., J. W. West, and D. S. Trammell. 2002. Effect of replacing corn silage with annual ryegrass silage on nutrient digestibility, intake, and milk yield for lactating dairy cows. J. Dairy Sci. 85:2277-2282.

Borreani, G. and E. Tabacco. 2006. The effect of a baler chopping system on fermentation and losses of wrapped big bales of alfalfa. Agron. J. 98:1-7.

Dewar, W. A., P. McDonald, and R. Whittenbury. 1963. The hydrolysis of grass hemicelluloses during ensilage. J. Sci. Food Agric. 14:411-417.

Dubois, M., K. A. Giles, J. K. Hamilton, P. A. Rebers, and F. Smith. 1956. Colorimetric method for determination of sugars and related substances. Anal. Chem. 28:350 -356.

Goering, H. K. and P. J. Van Soest. 1970. Forage Fiber Analyses (Apparatus, Reagents, Procedures, and Some Applications). Agric. Handbook No. 379. U.S. Department of Agriculture, Agricultural Research Service, Washington, DC.

Haigh, P. M. 1990. Effect of herbage water-soluble carbohydrate content and weather conditions at ensilage on the fermentation of grass silages made on commercial farms. Grass Forage Sci. 45:263-271.

Han, K. J., M. Collins, E. S. Vanzant, and C. T. Dougherty. 2006. Characteristics of baled silage made from first and second cuttings of wilted and severely-wilted forages. Grass Forage Sci. 61:22-31.

Han, K. J., M. E. McCormick, and R. Walz. 2008. Review of Louisiana and Mississippi Livestock Producer Sample Analyses. Southeast Research Station Field Day Summaries, 2008. Louisiana State University Agricultural Center, Baton Rouge, LA, USA. pp. 20-23.

Hersom, M. and W. E. Kunkle. 2003. Harvesting, Storing and
Feeding Foragers as Round Bale Silage. Pub. AN145, Dept. Anim. Sci., Florida Cooperative Extension Service, UF/IFAS, Gainsville, FL, USA. Oct. 2003. Revised Sep. 2011.

Huhnke, R. L., R. E. Muck, and M. E. Payton. 1997. Round bale silage storage losses of ryegrass and legume-grass forages. Appl. Eng. Agric. 13:451-457.

Johnson, R. R., T. L. Balwani, L. J. Johnson, K. E. McClure, and B. A. Dehority. 1966. Corn plant maturity. II. Effect on in vitro cellulose digestibility and soluble carbohydrate content. J. Anim. Sci. 25:617-623.

Martinson, K., W. Coblentz, and C. Sheaffer. 2011. The effect of harvest moisture and bale wrapping on forage quality, temperature, and mold in orchardgrass hay. J. Equine Vet. Sci. 31:711-716.

McCormick, M. E. and S. L. Fales. 1985. Ryegrass for silages: Stage of maturity and varietal influence on quality. Research Report. 465. ed. Univ. Georgia. Exp. Stn., ISSN 0072-128X.

McCormick, M. E., G. J. Cuomo and D. C. Blouin. 1998. Annul ryegrass stored as balage, haylage, or hay for lactating dairy cattle. J. Prod. Agric. 11:293-300.

McCormick, M. E. J. F. Beatty, and J. M. Gillespie. 2002. Ryegrass Bale Silage Research and Management Practices. Louisiana Agricultural Experiment Station Research Summary No. 144, pp. 1-16.

McCormick, M. E. 2006. Bale silage production issues. Proceedings of The 60th Southern Pasture and Forage Crop Improvement Conference, April 11-13, 2006; Auburn, AL, USA.

McGrath, D. 1988. Seasonal variation in the water-soluble carbohydrates of perennial and Italian ryegrass under cutting conditions. Irish J. Agric. Res. 27:131-139.

McEniry, J., P. O'Kiely, N. J. W. Clipson, P. D. Forristal, and E. M. Doyle. 2008. The microbiological and chemical composition of silage over the course of fermentation in round bales relative to that of silage made from unchopped and precisionchopped herbage in laboratory silos. Grass Forage Sci. 63:407420.

Muck, R. E. 1990. Dry matter level effects on alfalfa silage quality: II. Fermentation products and starch hydrolysis. Trans. ASAE. 33:373-381.

Muck, R. E. and K. J. Shinners. 2001. Conserved Forage (Silage and Hay): Progress and Priorities. International Grassland Congress.

www.internationalgrasslands.org/files/igc/publications/2001/te ma21-1.pdf Accessed Jun 20, 2011.

Muck, R. E. 2006. Fermentation characteristics of round-bale silages. Proceedings of The 60th Southern Pasture and Forage Crop Improvement Conference, April 11-13, 2006; Auburn, AL, USA.

Nicholson, J. W. G., R. E. McQueen, E. Charmley, and R. S. Bush. 1991. Forage conservation in round bales or silage bags: effect on ensiling characteristics and animal performance. Can. J. Anim. Sci. 71:1167-1180.

O’Brien, M., P. O. Kiely, P. D. Forristal, and H. T. Fuller. 2007a. Visible fungal growth on baled grass silage during the winter feeding season in Ireland and silage characteristics associated with the occurrence of fungi. Anim. Feed Sci. Technol. 139:234-256. 
O’Brien, M., P. O. Kiely, P. D. Forristal, and H. T. Fuller. 2007b. Quantification and identification of fungal propagules in wellmanaged baled grass silage and in normal on-farm produced bales. Anim. Feed Sci. Technol. 132:283-297.

Rhein, R. T., W. K. Coblentz, J. E. Turner, C. F. Rosenkrans Jr, R. K. Ogden, and D. W. Kellogg. 2005. Aerobic stability of wheat and orchardgrass round-bale silages during winter. J. Dairy Sci. $88: 1815-1826$.
Robertson, J. B. and P. J. Van Soest. 1981. The detergent system of analysis and its application to human foods. In: The Analysis of Dietary Fiber (Eds. W. P. T. James and O. Theander). Marcell Dekker, NY, USA. pp. 123-158.

SAS Institute. 2009. SAS/STAT 9.2 User's Guide 2nd ed., SAS Inst., Cary, NC, USA.

Sukhija, P. S. and D. L. Palmquist. 1988. Rapid method for determination of total fatty acid content and composition of feedstuffs and feces. J. Agric. Food Chem. 36:1202-1206. 